\title{
CORRESPONDENCE.
}

\section{ON THE ADJUSTMENT OF PREMIUMS FOR LIFE ASSURANCE IN REFERENCE TO EXTRA RISKS. \\ To the Editor.}

Sir, - In my former letter I have examined most of the cases of Assurance on single lives likely to present themselves in practice, and I have shewn how far the ordinary method of determining the Extra Preminm in such cases agrees with the supposition of a constant extra risk, upon which that method is professedly based. The truth or error of the supposition is really immaterial, the point at issue being one of consistency only,-but as the importance to be attached to the subject will doubtless be much enhanced if it should appear that, as regards climatic influences, the hypothesis of a constant or uniform extra risk is actually borne out by such facts as are within our reach, I proceed now to shew that such is in reality the case.

Indeed the striking similarity in the progression of the series contained in the last two columns of the Table given at p. 164 is sufficient to beget a suspicion of the fact asserted. The two columns in question comprise the results of a comparison of the hypothetical with the actual annuity values for five equidistant ages, from 20 to 60 both inclusive. The following 
Table, however, which gives the mortality for each interval, must be considered much stronger evidence,-each of the six terms of which it consists forming a distinct and entirely independent testimony to the truth of the hypothesis. It contains the average "rate" and also the corresponding "force" of mortality in the several indicated intervals of age, first by Mr. Neison's Bengal Military Table, and secondly by the Carlisle Table. The difference between these, which is given in the next column, is the extra force which by the hypothesis is supposed to be constant for all ages. The result, $I$ hold, accords with the hypothesis fully within the limits of the error which we know, by ample experience, attaches even to the best and most trustworthy Tables.

\begin{tabular}{|c|c|c|c|c|c|}
\hline \multirow[b]{2}{*}{ Ages. } & \multicolumn{2}{|c|}{$\begin{array}{c}\text { AVERAGE RATE OF } \\
\text { MORTALITY. }\end{array}$} & \multicolumn{2}{|c|}{$\begin{array}{c}\text { Corresponding Forca } \\
\text { OF Mortality. }\end{array}$} & \multirow{2}{*}{$\begin{array}{l}\text { Differences } \\
\text { of Colnmns } \\
\text { (3) and (4). }\end{array}$} \\
\hline & $\begin{array}{l}(1) \\
\text { By Carlisle } \\
\text { Table. }\end{array}$ & $\begin{array}{l}\text { (2) } \\
\text { By Nelson's } \\
\text { Bengal } \\
\text { M. Table. }\end{array}$ & $\begin{array}{c}\text { (3) } \\
\text { By Carlisle } \\
\text { Table. }\end{array}$ & $\begin{array}{l}\text { (4) } \\
\text { By Neison's } \\
\text { Bengal } \\
\text { M. Table. }\end{array}$ & \\
\hline $\begin{array}{l}21-24 \\
25-32 \\
33-40 \\
41-48 \\
49-56 \\
57-64\end{array}$ & $\begin{array}{l}\cdot 00702 \\
\cdot 00893 \\
\cdot 01099 \\
\cdot 01446 \\
\cdot 01582 \\
\cdot 03226\end{array}$ & $\begin{array}{l}\cdot 02307 \\
.02534 \\
\cdot 02860 \\
\cdot 03140 \\
\cdot 03318 \\
\cdot 04787\end{array}$ & $\begin{array}{l}\cdot 00704 \\
\cdot 00897 \\
\cdot 01105 \\
\cdot 01457 \\
\cdot 01595 \\
\cdot 03279\end{array}$ & $\begin{array}{r}\cdot 02334 \\
\cdot 02567 \\
.02902 \\
.03190 \\
\cdot 03374 \\
\cdot 04904\end{array}$ & $\begin{array}{l}\cdot 01630 \\
.01670 \\
.01797 \\
.01733 \\
\cdot 01779 \\
\cdot 01625\end{array}$ \\
\hline $\begin{array}{c}\text { Sum of each } \\
\text { Column } \\
\text { Average of do. }\end{array}$ & $\begin{array}{r}\cdot 08948 \\
\cdot 01491\end{array}$ & $\begin{array}{r}\cdot 18946 \\
\cdot 03158\end{array}$ & $\begin{array}{c}.09037 \\
.01506\end{array}$ & $\begin{array}{c}\cdot 19271 \\
\cdot 03212\end{array}$ & $\begin{array}{r}\cdot 10234 \\
.01706\end{array}$ \\
\hline
\end{tabular}

The first interval comprises four years only, the remainder eight each, so that the last interval terminates with the age 64, with which Mr. Neison's data are exhausted. The "force" of mortality is dednced from the corresponding "rate" $(\mu)$ by the formula $\frac{\mu}{1-\frac{1}{2} \mu}$, which, if I recollect rightly, is due to Dr. Farr. It denotes the force of mortality at the middle, not at the commencement, of the year,-and may be thus demonstrated:

$$
\begin{aligned}
\frac{d \mathrm{~L}_{x+\frac{1}{2}}}{d x} & =\Delta \mathrm{L}_{x}-\frac{1}{24} \Delta^{3} \mathrm{~L}_{x-1}+\ldots \text { (See Vol. 13, p. 353) } \\
\mathrm{L}_{x+\frac{1}{4}} & =\left(\mathrm{L}_{x+\frac{1}{3}}\right)-\frac{1}{2} \cdot \frac{1}{2^{2}}\left(\Delta^{2} \mathrm{~L}_{x-\frac{1}{4}}\right)+\frac{1.3}{2.4} \cdot \frac{1}{2^{4}}\left(\Delta^{4} \mathrm{~L}_{x-\frac{3}{2}}\right)-\ldots
\end{aligned}
$$

where $\left(\mathrm{L}_{x+\frac{1}{2}}\right),\left(\Delta^{2} \mathrm{~L}_{x+\frac{1}{2}}\right)$, \&c., denote the mean of two successive terms, as $\frac{1}{2}\left(\mathrm{~L}_{x}+\mathrm{L}_{x+1}\right), \frac{1}{2}\left(\Delta^{2} \mathrm{~L}_{x}+\Delta^{2} \mathrm{~L}_{x+1}\right)$, \&c. Hence stopping at the first term of each series we have, $\left(\mathrm{L}_{x+\frac{1}{x}}\right)$ being equal to $\mathrm{L}_{x}+\frac{1}{2} \Delta \mathrm{L}_{x}$,

$$
\mathrm{F}_{x+\frac{1}{2}}=-\frac{d \mathrm{~L}_{x+\frac{1}{3}}}{\mathrm{~L}_{x+\frac{1}{2}} d x}=\frac{-\Delta \mathrm{L}_{x}}{\mathrm{~L}_{x}+\frac{1}{2} \Delta \mathrm{L}_{x}}=\frac{-\frac{\Delta \mathrm{L}_{x}}{\mathrm{~L}_{x}}}{1+\frac{1}{2} \cdot \frac{\Delta \mathrm{L}_{x}}{\mathrm{~L}_{x}}}=\frac{\mu_{x}}{1-\frac{1}{2} \mu_{x}} .
$$

* I am not aware that this formula has ever been given before. It will be found very convenient for bisecting the interval of two successive terms of a series; and may be easily deduced from the ordinary formula. 
Having thus ascertained the law which (to the best of our information) appears to govern the influence of climate upon European life in India, we are justified in inferring that the same law operates in other countries. Indeed the conclusion is inevitable until it shall have been shewn, in any particular instance, that some other law prevails. Our requirements, therefore, for determining the true law of mortality among Europeans residing abroad are limited to the determination of the values of the single constant representing the extra risk for the respective climates. And herein lies the great importance of the discovery of general laws, viz., that by their aid we are enabled to economize our facts, and, by bringing them all to bear upon a single point, compel them, as it were, to yield us information which we should otherwise be unable to obtain. As an instance of this I may refer to the Tables published in Vol. 7, p 134, of this Journal, embodying a considerable collection of facts relating to foreign risks. These facts, although insufficient to serve for the construction of independent Tables of mortality for different climates, are yet numerous enough to enable us to determine, with a tolerable degree of accuracy, the single constant required for the adjustment of the Home lable to each case; and I may perhaps on some future occasion ask the indulgence of your readers for an analysis of the experience referred to.

I am, Sir,

Your very obedient servant,

$$
\begin{array}{r}
\text { 10, King Street, Cheapside, } \\
\text { 27th February, } 1868 .
\end{array}
$$

W. M. MAKEHAM.

\section{DEMONSTRATION OF A FORMULA FOR INTERPOLATION.}

\section{To the Editor of the Assurance Magazine.}

Sir,-I have been asked on more than one occasion how the formula were obtained which I used in graduating the mortality among the males of the peerage (Assurance Magazine, vol. xii., p. 221); and as the question may not be without interest to some readers of the Journal, I will now state the method.

I had noticed the following resemblance between two sets of expressions. If a series $u_{0}, u_{5}, u_{10}$, \&c. is differenced, and $\Delta u_{0}, \Delta^{2} u_{0}, \ldots$ be the initial terms of each order of differences; $\Delta^{4} u_{0}$ being constant; then, as is shown on page 23 of the current volume of the Journal,

$$
\begin{array}{rlrl}
\delta u_{0} & =\frac{1}{5} \Delta u_{0}-\frac{2}{5^{2}} \Delta^{2} u_{0}+\frac{6}{5^{3}} \Delta^{3} u_{0}-\frac{21}{5^{4}} \Delta^{4} u_{0} \\
\delta^{2} u_{0} & = & \frac{1}{5^{2}} \Delta^{2} u_{0}-\frac{4}{5^{3}} \Delta^{3} u_{0}+\frac{16}{5^{4}} \Delta^{4} u_{0} \\
\delta^{3} u_{0}= & \frac{1}{5^{3}} \Delta^{3} u_{0}-\frac{6}{5^{4}} \Delta^{4} u_{0} \\
\delta^{4} u_{0}= & \frac{1}{5^{4}} \Delta^{4} u_{0}
\end{array}
$$

